\title{
Arsenic Accumulation and Speciation in Maize as Affected by Inoculation with Arbuscular Mycorrhizal Fungus Glomus mosseae
}

\author{
Yang Yu, Shuzhen Zhang, * Honglin Huang, Lei Luo, and Bei Wen \\ State Key Laboratory of Environmental Chemistry and Ecotoxicology, Research Center for \\ Eco-Environmental Sciences, Chinese Academy of Sciences, P.O. Box 2871, Beijing 100085, China
}

\begin{abstract}
Effects of inoculation with arbuscular mycorrhizal (AM) fungus (Glomus mosseae) on arsenic (As) accumulation and speciation in maize were investigated by using As spiked soil at the application levels of $0,25,50$, and $100 \mathrm{mg} \mathrm{kg}^{-1}$. Inorganic As was the major species in plants, and mycorrhizal inoculation generally decreased concentrations of arsenite $[\mathrm{As}$ (III)] in maize roots and concentrations of $\mathrm{As}$ (III) and arsenate $[\mathrm{As}(\mathrm{V})]$ in the shoots. Dimethylarsenic acid $(\mathrm{DMA})$ concentrations (detected in every plant sample) were higher in maize shoots for mycorrhizal than for nonmycorrhizal treatment, but no significant differences were observed for roots. Monomethylarsenic acid (MMA) was only detected in roots with mycorrhizal colonization. The uptake of $A s(V)$ was much lower by excised mycorrhizal than nonmycorrhizal roots, and the differences for the uptake of As(III) were negligible. Arsenate reductase (AR) activity was detected in maize roots, and it was reduced with mycorrhizal inoculation. Activities of peroxidase (POD) and superoxide dismutase (SOD) were detected in both maize shoots and roots, and they were suppressed by mycorrhizal inoculation. AM inoculation inhibited the uptake of $\mathrm{As}(\mathrm{V})$ and its reduction to As(III), reducing oxidation stress and thereby alleviating As toxicity to the host plant.
\end{abstract}

KEYWORDS: Arbuscular mycorrhizal fungus; arsenic speciation; uptake; arsenate reductase activity; antioxidative enzyme activity

\section{INTRODUCTION}

Arsenic is a ubiquitous trace metalloid (l) that can be found throughout the world in soils polluted by mining and smelting industries and coal burning, particularly in South East Asia (2). Arsenic in soil can enter the food chain via plant uptake and cause adverse effects on human health (3).

Different As species such as arsenate $[\mathrm{As}(\mathrm{V})]$, arsenite [As(III)], monomethylarsonic acid (MAA), and dimethylarsinic acid (DMA) have been found in soils and plants. They have different chemical behavior and are thought to be taken up by roots and transported within plants by different ways. Arsenate acts as a phosphate analogue and is transported across the plasma membrane via phosphate cotransport systems (2). Arsenite has been evidenced to transport into rice roots via glycerol transporting channels (4). Toxic effects of As are highly dependent on its speciation. Inorganic As $[\mathrm{As}(\mathrm{III})$ and $\mathrm{As}(\mathrm{V})]$ is generally more toxic than the organic species, and $\mathrm{As}(\mathrm{III})$ is more toxic than $\mathrm{As}(\mathrm{V})(1,2,5)$.

Arbuscular mycorrhizal (AM) fungi are ubiquitous in the rhizosphere, forming symbiotic associations with roots of the majority of plant species (6). Their capacity to enhance the tolerance of host plants to As contamination in soil has been addressed $(7,8)$. AM fungi have also been reported to reduce plant uptake of As such as by the fern Pteris vittata

*Corresponding author. Tel: +861062849683 . Fax: +8610 62923563. E-mail: szzhang@rcees.ac.cn.
L (9), lentil (10), alfalfa (11), tomato (12), and sunflower (13). Considering the interactions between AM fungi with soil microorganisms in the rhizosphere and their influence on plant uptake of nutrition such as $\mathrm{P}$, we speculated that AM fungi might influence As speciation in soil and plant growth in As contaminated soil. To our knowledge, such information is lacking, and the knowledge is essential for us to understand the effect of AM fungi on the biogeochemistry of As in the soil-plant system.

Reduction and methylation of As can generate reactive oxygen species (ROS) and damage DNA, proteins, and lipids (2). Plants have evolved a variety of mechanisms to alleviate the deleterious effects caused by ROS, generally through the production of various antioxidative enzymes such as superoxide dismutase (SOD) and peroxidase (POD). For example, SOD, a metallo-enzyme, can catalyze the dismutation of $\mathrm{O}_{2}^{--}$ into $\mathrm{H}_{2} \mathrm{O}_{2}$ and $\mathrm{O}_{2}$, and subsequently $\mathrm{H}_{2} \mathrm{O}_{2}$ can be effectively scavenged by POD. A previous study has found that lipid peroxidation and SOD activities are correlated with increasing $\mathrm{As}(\mathrm{V})$ concentrations in Holcus lanatus L. (14). Srivastava et al. (15) have observed a higher antioxidative enzyme activity in correspondence with As accumulation in As-treated Pteris vittata. However, $\mathrm{As}(\mathrm{V})$ in most organisms can be enzymatically reduced to As(III) (16). Arsenate reductase (AR) has been detected in terrestrial plants, including ferns, rice, and Arabidopsis (17), and has been confirmed to play an important role in plant accumulation and detoxification of As (18). 
The aim of the present study was to investigate the influence of AM inoculation on As accumulation and speciation in maize growing in a soil artificially contaminated with various levels of $\mathrm{As}(\mathrm{V})$. The uptake of $\mathrm{As}(\mathrm{V})$ and $\mathrm{As}(\mathrm{III})$ by excised roots was characterized, and activities of AR and antioxidative enzymes were analyzed and compared between mycorrhizal and nonmycorrhizal plants in order to understand the mechanisms involved in the influence of AM fungus on plant accumulation of different As species and the resistance of mycorrhizal plant to As contamination in soil.

\section{MATERIALS AND METHODS}

Inoculum and Soil Preparation. Inoculum of the AM fungus, Glomus mosseae, isolated from a noncontaminated soil, was propagated for 10 weeks in pot culture on broomcorn (Sorghum vulgare Pers.) plants grown in a soil-sand mixture in a greenhouse. The inoculum, which was air-dried and passed through a 2-mm sieve, consisted of spores, mycelium, sandy soil, and root fragments containing approximately 60 spores $\mathrm{g}^{-1}$ soil (dry weight soil basis).

A sandy soil (Alfisol) was collected from a farm near Beijing. It was dried and passed through a $2-\mathrm{mm}$ sieve. The soil has the following properties (on a dry weight soil basis): $\mathrm{pH}$ (1:2.5 soil to water), 8.41; organic matter, $0.39 \%$; $0.5 \mathrm{~mol} \mathrm{~L}{ }^{-1} \mathrm{NaHCO}_{3^{-}}$ extractable $\mathrm{P}, 2.75 \mathrm{mg} \mathrm{kg}^{-1}$; and $0.5 \mathrm{~mol} \mathrm{~L}^{-1} \mathrm{NaHCO}_{3}$-extractable As, $0.18 \mathrm{mg} \mathrm{kg}^{-1}$. The soil was sterilized by $\gamma$-irradiation (10 kGy, $10 \mathrm{MeV} \gamma$ ray) for the elimination of indigenous AM fungi and received an application of $200 \mathrm{mg} \mathrm{kg}^{-1} \mathrm{~N}\left(\mathrm{NH}_{4} \mathrm{NO}_{3}\right)$, $30 \mathrm{mg} \mathrm{kg}^{-1} \mathrm{P}\left(\mathrm{KH}_{2} \mathrm{PO}_{4}\right)$, and $150 \mathrm{mg} \mathrm{kg}^{-1} \mathrm{~K}\left(\mathrm{~K}_{2} \mathrm{SO}_{4}\right)$ as a basal fertilizer.

Plant Growth and Harvest. Four replicates for each As treatment, $0 \mathrm{mg} \mathrm{kg}^{-1}, 25 \mathrm{mg} \mathrm{kg}^{-1}, 50 \mathrm{mg} \mathrm{kg}^{-1}$, and $100 \mathrm{mg}$ $\mathrm{kg}^{-1}$, were applied to mycorrhizal and nonmycorrhizal treatments. Each pot received a mixture of $750 \mathrm{~g}$ soil and $50 \mathrm{~g}$ inoculum for mycorrhizal treatment or sterilized inoculum plus $15 \mathrm{~mL}$ of inoculum washings filtered through a $37 \mu \mathrm{m}$ filter paper for nonmycorrhizal treatment. Arsenate was added as $\mathrm{Na}_{2} \mathrm{HAsO}_{4} \cdot 7 \mathrm{H}_{2} \mathrm{O}$ in solution. The pots were allowed to equilibrate for a period of 4 weeks in a greenhouse by undergoing four cycles of saturation with distilled water and air drying. Seeds of maize (Zea mays L.) were surface sterilized in a 10\% (v/v) solution of hydrogen peroxide and then pregerminated on a moist filter paper for 3 days. Four seedlings were transplanted into each pot, and two uniform seedlings were left after 4 days. The experiment was carried out in a controlled environment glasshouse with a photoperiod of $14 \mathrm{~h}$ at a light intensity of $250 \mu \mathrm{mol} \mathrm{m} \mathrm{m}^{-2} \mathrm{~s}^{-1}$ provided by supplementary illumination. The temperature was $25{ }^{\circ} \mathrm{C}$ at daytime and $18{ }^{\circ} \mathrm{C}$ at night. The moisture content of the soil was maintained at $50 \%$ of water holding capacity by regular watering.

Plants were harvested after 8 weeks of growth. Shoots and roots were separately harvested. Root fragments were collected by sieving the soil and adding them to the root samples. Roots were first carefully washed with tap water to remove any adhering soil particles. Then roots and shoots were thoroughly rinsed with distilled water, blotted dry, and weighed. A subsample of fresh roots was taken from each pot, cleared, and stained for the determination of the proportion of root length colonized by the AM fungus and quantified by a grid line intersect method (19). Some fresh roots and shoots were frozen by liquid nitrogen and then stored at $-80{ }^{\circ} \mathrm{C}$ for enzyme analysis. The remaining plant samples were freeze-dried, ground, and stored at $4{ }^{\circ} \mathrm{C}$, and the dry weights were recorded. The fresh to dry root ratio was used to estimate the total dry mass of roots. Only the rhizosphere soils were sampled from each pot considering the interactions between roots/mycorrhizas and As and the importance of As biogeochemistry in the rhizosphere soil. The soil that required continued, vigorous rubbing and shaking of the root system was classified as rhizosphere soil (20).
Analyses of P, Total As, and As Speciation. Subsamples of $0.1 \mathrm{~g}$ dry plant materials were digested with $2.5 \mathrm{~mL}$ of concentrated $\mathrm{HNO}_{3}$ and $2.5 \mathrm{~mL}$ of $\mathrm{H}_{2} \mathrm{O}_{2}$, and $0.1 \mathrm{~g}$ of dry soil samples with $2.5 \mathrm{~mL}$ of concentrated $\mathrm{HNO}_{3}$ and $2 \mathrm{~mL}$ of concentrated $\mathrm{HClO}_{4}$. The digestion tubes were heated on a heating block at $120{ }^{\circ} \mathrm{C}$ for $1 \mathrm{~h}$ and then at $180{ }^{\circ} \mathrm{C}$ to evaporate the samples to near dryness. Reagent blank and certified reference material of tea (GBW 08505) were included to verify the accuracy and precision of the digestion procedure, and subsequent analysis and the recovery rates were within $95 \pm 10 \%$. Arsenic was determined by hydride generation atomic fluorescence spectrometry (HG-AFS, AF-610A atomic fluorescence spectrophotometer, Beijing RuiLi Instrumental Company, Beijing, China), and $\mathrm{P}$ was determined by the Molybdenum blue method.

Two grams of soil samples or $0.2 \mathrm{~g}$ of freeze-dried powdered plant samples were ultrasonically extracted with $10 \mathrm{~mL}$ of $1: 1$ methanol/water for $2 \mathrm{~h}(21)$. The samples were centrifuged, and the supernatant was decanted into a polyethylene bottle. The procedure was repeated with the residual pellet, and the two extracts were combined. The extraction solutions were then airdried with nitrogen to remove methanol and regenerated in a smaller volume $(1-5 \mathrm{~mL})$ with double deionized water. The spike recoveries, individual test for As(V), As(III), MMA, and DMA, were within $100 \pm 10 \%$. Extraction efficiency of As, defined as the ratio of As concentration obtained by extraction to that by nitric acid digestion, ranged from 50 to $70 \%$ for roots and 75 to $95 \%$ for shoots, respectively.

Arsenic speciation in the sample extracts was determined by using HPLC (Agilent 1200 series HPLC) coupled to ICPMS (Agilent 7500c ICP-MS). An anion exchange column at $150 \mathrm{~mm} \times 4.6 \mathrm{~mm}$ i.d. was used and $2 \mathrm{mM} / 0.2 \mathrm{mM}$ phosphate buffer/EDTA eluent (pH 6.0) was used to detect As(V), As(III), MMA, and DMA in less than $10 \mathrm{~min}$. One guard column at $10 \mathrm{~mm} \times 4.6 \mathrm{~mm}$ i.d. was used to protect the main column. Each As species in the extracts was verified by the coincidence of retention times with standards. Stock solutions of As(III), DMA, MMA, and $\mathrm{As}(\mathrm{V})$ were prepared from $\mathrm{NaAsO}_{2}, \mathrm{CH}_{3} \mathrm{AsO}(\mathrm{ONa})_{2}$, $\left(\mathrm{CH}_{3}\right)_{2} \mathrm{AsO}(\mathrm{OH})$, and $\mathrm{Na}_{2} \mathrm{HAsO}_{4} \cdot 7 \mathrm{H}_{2} \mathrm{O}$. Detection limits were $0.1,0.2,0.1$, and $0.1 \mu \mathrm{g} \mathrm{L}^{-1}$ for As(III), As(V), DMA, and MMA, respectively. Quality assurance was obtained through the use of blanks, standard curves, standard check solutions, and spiked samples, which were run during sample analysis.

Uptake Kinetics of As(V) and As(III). Plants for the experiment of root uptake of $\mathrm{As}(\mathrm{V})$ and $\mathrm{As}(\mathrm{III})$ were prepared separately. Methods for inoculation and plant growth in nonarsenic soil were the same as described above. Experimental method for As uptake by roots was adopted from the one by Gonzalez-Chavez et al. (7). Roots of both nonmycorrhizal and mycorrhizal plants were first carefully washed by soaking in water to remove soil particles and excised at the basal node. The excised roots $(0.2-0.5 \mathrm{~g}$ fresh weight) were incubated in aerated test solution [containing $5.0 \mathrm{mM}$ MES and $0.5 \mathrm{mM} \mathrm{Ca}\left(\mathrm{NO}_{3}\right)_{2}$, adjusted to $\mathrm{pH} 5$ using $\mathrm{KOH}$ ] for $30 \mathrm{~min}$ at $25^{\circ} \mathrm{C}$ and then transferred into aerated test solutions containing different concentrations of $\mathrm{As}(\mathrm{V})$ or $\mathrm{As}(\mathrm{III})$. After the termination of As exposure for $20 \mathrm{~min}$, the roots were rinsed in ice-cold phosphate solution containing $1 \mathrm{mM} \mathrm{K} \mathrm{HPO}_{4}$ to remove the absorbed As from the root free space and to stop further root activity. The roots were then oven-dried at $70{ }^{\circ} \mathrm{C}$ for 2 days and weighed. Digestion and analysis of the samples were conducted following the methods described above.

Enzyme Analysis. Arsenic reductase (AR) activity was assayed using the coupled enzymatic reaction described by Duan et al. (17) with some modifications. Two grams of fresh plant materials were ground and homogenized to a fine paste in $10 \mathrm{~mL}$ of extraction buffer (50 mM MOPS and $50 \mathrm{mM}$ MES, adjusted to $\mathrm{pH} 6.5$ with $\mathrm{NaOH}$ ), filtered, centrifuged, then purified with Sephadex PD-10 desalting columns. All steps were performed on ice, and the supernatant was stored at $4{ }^{\circ} \mathrm{C}$ prior to analysis of AR activity. The assay of AR was performed in $50 \mathrm{mM}$ MOPS and $50 \mathrm{mM}$ MES, pH 6.5, containing $1.5 \mathrm{mM}$ NADPH, 1 unit 
yeast glutathione reductase, $1 \mathrm{mM} \mathrm{GSH}$, and $10 \mathrm{mM}$ sodium arsenate. Plant extracts were preincubated for $5 \mathrm{~min}$ in the buffer containing glutathione reductase and GSH, and then NADPH and sodium arsenate were added to start the reaction. AR activity was monitored by the decrease of NADPH absorbance at $340 \mathrm{~nm}$, and NADPH oxidation was calculated using a molar extinction coefficient of 6200 for NADPH at $340 \mathrm{~nm}$ and expressed in nkat $\mathrm{mg}^{-1}$ protein. One nkat is defined as the amount of enzyme required to oxidize $1 \mathrm{nmol} \mathrm{NADPH}$ in $1 \mathrm{~s}$.

A half gram of fresh plant samples were ground and homogenized in $10 \mathrm{~mL}$ of solution containing $50 \mathrm{mM}$ potassium phosphate buffer and $1 \%(\mathrm{w} / \mathrm{v})$ polyvinylpyrrolidone $(\mathrm{pH} 7.8)$ on an ice-bath. The homogenate was centrifuged at $8000 \mathrm{~g}$ for 15 min at $4{ }^{\circ} \mathrm{C}$. The supernatant was stored at $4{ }^{\circ} \mathrm{C}$ prior to the analysis of SOD and POD activities, and the soluble protein contents. POD activity was assayed following the method of Polle et al. (22). Changes in the absorbance of brown guaiacol at $460 \mathrm{~nm}$ in the presence of $\mathrm{H}_{2} \mathrm{O}_{2}$ were recorded for calculating POD activity. The enzyme activity was defined as the nmol of $\mathrm{H}_{2} \mathrm{O}_{2}$ oxidized $\mathrm{min}^{-1} \mathrm{mg}^{-1}$ protein. SOD activity was measured by the spectrophotometric method. The assay was performed in terms of SOD ability to inhibit the reduction of $\rho$-nitroblue tetrazolium chloride (NBT) to formazan by the superoxide radical. One unit of SOD activity (U) was defined as the amount of enzyme required to inhibit NBT reduction by $50 \%$ measured at $560 \mathrm{~nm}$ and expressed in $\mathrm{U} \mathrm{mg}^{-1}$ protein. Protein contents were determined using Coomassie Brilliant Blue G-250 as dye and bovine serum albumin as the standard. All spectrophotometric analyses were conducted using an ultraviolet-visible spectrophotometer (U-3010, Hitachi Ltd., Tokyo, Japan).

Statistical Analysis. All results were expressed as an average of four replications. Treatment effects were determined by twoway analysis of variance using SPSS 11.0 software.

\section{RESULTS}

Colonization Rate, Biomass, and Concentrations of $\mathbf{P}$ and As. No mycorrhizal colonization was observed in the roots of noninoculated plants, while mycorrhizal plants had 74, 72, 76 , and $69 \%$ of root colonization rate at As addition levels of $0,25,50$, and $100 \mathrm{mg} \mathrm{kg}^{-1}$, respectively, and As concentration in soil did not significantly affect mycorrhizal inoculation $(P>0.05)$.

Table 1 displays the maize biomass, $P$ concentrations, and concentration and total accumulation of As in maize. Both root and shoot biomass decreased markedly when As was applied at 50 and $100 \mathrm{mg} \mathrm{kg}^{-1}$. Mycorrhizal inoculation increased the root and shoot dry weights significantly
$(P<0.001)$, especially when As was applied at $100 \mathrm{mg} \mathrm{kg}^{-1}$ where the biomass of mycorrhizal maize was almost twice as much as that of nonmycorrhizal plant. Mycorrhizal inoculation increased $\mathrm{P}$ concentration in both roots and shoots at all As application levels $(P<0.01)$. The concentration and total accumulation of As increased consistently in shoots and roots of both nonmycorrhizal and mycorrhizal plants with increasing application rate of As in soil. Mycorrhizal inoculation significantly reduced As concentration in both maize roots and shoots $(P<0.001)$. The total As accumulation in roots and shoots were lower in mycorrhizal than in nonmycorrhizal treatments without As addition or at low As additional level (e.g., $25 \mathrm{mg} \mathrm{kg}^{-1}$ ), while the opposite pattern was observed when As was applied at high concentration (e.g., 50 and $100 \mathrm{mg} \mathrm{kg}^{-1}$ ), which could be ascribed to the limited influence of mycorrhizal inoculation on plant biomass at low As addition levels and a significant influence at high As addition levels.

Arsenic Speciation. Inorganic As was the major species found in the rhizosphere soil and plant samples and accounted for more than $97 \%$ of the total contents. Concentrations of $\mathrm{As}(\mathrm{V})$ and $\mathrm{As}(\mathrm{III})$ in maize roots and shoots and the rhizosphere soils after plant harvest are given in Figure 1. As(V) and $\mathrm{As}(\mathrm{III})$ were detected in all of the samples except that no As(III) was detected in the nonarsenic addition soil. Concentrations of As(V) and As(III) increased consistently in the rhizosphere soils, shoots, and roots with increasing As application rate. In soil, As(V) was the predominant species $(91-100 \%)$, and mycorrhizal inoculation decreased the concentrations of both $\mathrm{As}(\mathrm{V})$ and $\mathrm{As}(\mathrm{III})$. Arsenite was the major species present in maize roots $(48-85 \%)$ and shoots $(68-93 \%)$. AM inoculated roots accumulated consistently more $\mathrm{As}(\mathrm{V})$ and less $\mathrm{As}(\mathrm{III})$ than nonmycorrhizal roots. Shoot concentrations of $\mathrm{As}(\mathrm{V})$ and As(III) were all obviously lower in the mycorrhizal than in the nonmycorrhizal treatment $(P<0.001)$.

Concentrations of organic As species (MMA and DMA) in the rhizosphere soils and plants are given in Table 2. DMA was detected in all of the samples irrespective of As application rates and mycorrhizal treatments with only one exception for the control treatment without As addition to soil, whereas MMA was only found in the rhizosphere soils and roots for nonmycorrhizal treatment. Both MMA and DMA increased with increasing As concentration in the soils. DMA concentrations were observed lower in the soils $(P<0.05)$ and higher in maize shoots $(P<0.05)$ for

Table 1. Dry Biomass, Concentrations of $P$, and Concentration and Total Accumulation of As in Roots and Shoots of Maize Inoculated with or without AM Fungus $($ Mean $\pm \mathrm{SE}, n=4)$

\begin{tabular}{|c|c|c|c|c|c|c|c|c|c|}
\hline \multirow[b]{2}{*}{ As addition ( $\left.\mathrm{mg} \mathrm{kg}^{-1}\right)$} & \multirow[b]{2}{*}{ inoculation treatment } & \multicolumn{2}{|c|}{ dry biomass (g) } & \multicolumn{2}{|c|}{$\mathrm{P}$ concentration $\left(\mathrm{mg} \mathrm{g}^{-1}\right)$} & \multicolumn{2}{|c|}{ As concentration $\left(\mathrm{mg} \mathrm{kg}^{-1}\right)$} & \multicolumn{2}{|c|}{ total As accumulation $\left(\mu \mathrm{g} \mathrm{pot}{ }^{-1}\right.$} \\
\hline & & root & shoot & root & shoot & root & shoot & root & shoot \\
\hline \multirow[t]{2}{*}{0} & $\mathrm{NM}^{a}$ & $4.3 \pm 0.1$ & $7.6 \pm 0.6$ & $0.63 \pm 0.04$ & $0.89 \pm 0.07$ & $1.5 \pm 0.1$ & $0.14 \pm 0.02$ & $6.3 \pm 0.7$ & $1.0 \pm 0.1$ \\
\hline & M & $4.9 \pm 0.3$ & $9.6 \pm 0.4$ & $1.10 \pm 0.07$ & $1.43 \pm 0.05$ & $1.1 \pm 0.2$ & $0.08 \pm 0.02$ & $5.2 \pm 1.3$ & $0.8 \pm 0.2$ \\
\hline \multirow[t]{2}{*}{25} & NM & $4.6 \pm 0.3$ & $7.0 \pm 0.1$ & $0.59 \pm 0.11$ & $0.98 \pm 0.06$ & $32.4 \pm 2.4$ & $1.17 \pm 0.13$ & $149.7 \pm 11.6$ & $8.1 \pm 0.7$ \\
\hline & M & $6.4 \pm 0.2$ & $9.2 \pm 0.3$ & $0.90 \pm 0.04$ & $1.45 \pm 0.03$ & $21.2 \pm 5.1$ & $0.72 \pm 0.13$ & $133.8 \pm 30.8$ & $6.6 \pm 1.3$ \\
\hline \multirow[t]{2}{*}{50} & NM & $3.6 \pm 0.3$ & $4.4 \pm 0.1$ & $0.61 \pm 0.07$ & $0.80 \pm 0.10$ & $129.2 \pm 17.2$ & $1.56 \pm 0.15$ & $461.7 \pm 37.8$ & $6.8 \pm 0.8$ \\
\hline & $M$ & $6.1 \pm 0.4$ & $7.8 \pm 0.6$ & $0.95 \pm 0.12$ & $1.34 \pm 0.07$ & $82.1 \pm 10.6$ & $1.04 \pm 0.21$ & $491.6 \pm 26.0$ & $8.2 \pm 2.4$ \\
\hline \multirow[t]{2}{*}{100} & NM & $2.2 \pm 0.1$ & $2.8 \pm 0.1$ & $0.72 \pm 0.06$ & $0.81 \pm 0.08$ & $175.2 \pm 9.3$ & $2.47 \pm 0.23$ & $381.1 \pm 28.6$ & $6.9 \pm 0.5$ \\
\hline & $M$ & $4.2 \pm 0.1$ & $6.2 \pm 0.3$ & $1.08 \pm 0.13$ & $1.60 \pm 0.11$ & $121.7 \pm 10.4$ & $1.63 \pm 0.25$ & $505.7 \pm 17.9$ & $10.2 \pm 2.4$ \\
\hline \multicolumn{10}{|l|}{ significance of } \\
\hline inoculation (I) & & *** & $* * *$ & *** & ** & *** & *** & *** & $* * *$ \\
\hline arsenic (As) & & $\star \star \star *$ & *** & NS & NS & $* \star *$ & $* * *$ & $\star \star \star *$ & $* \star *$ \\
\hline$I \times A s$ & & $* * *$ & $* * *$ & NS & NS & $* * *$ & $* * *$ & $* * *$ & $* * *$ \\
\hline
\end{tabular}

\footnotetext{
${ }^{a} \mathrm{NM}$ and $\mathrm{M}$ represent nonmycorrhizal and mycorrhizal treatments, respectively. ${ }^{* *}, P<0.001 ;{ }^{* \star}, P<0.01 ;{ }^{*}, P<0.05$; NS, not significant.
} 
mycorrhizal treatment compared with nonmycorrhizal treatment; however, such differences were not statistically significant for roots $(P>0.05)$.

Effects of Inoculation with AM Fungus on the Uptake Kinetics of $\mathbf{A s}(\mathbf{V})$ and As(III). The uptake of As(V) and As (III) by maize roots showed a hyperbolic increase with increasing concentration of As in solution (Figure 2), and the uptake kinetics were adequately described by the Michaelis-Menten function (Table 3). The uptake of As(V) was much higher than that of As(III) by both mycorrhizal and nonmycorrhizal roots. A significant difference for the uptake of $\mathrm{As}(\mathrm{V})$ existed between mycorrhizal and nonmycorrhizal roots. Uptake of As(V) by mycorrhizal roots had a lower $V_{\max }$ value and higher $K_{m}$ value than that by
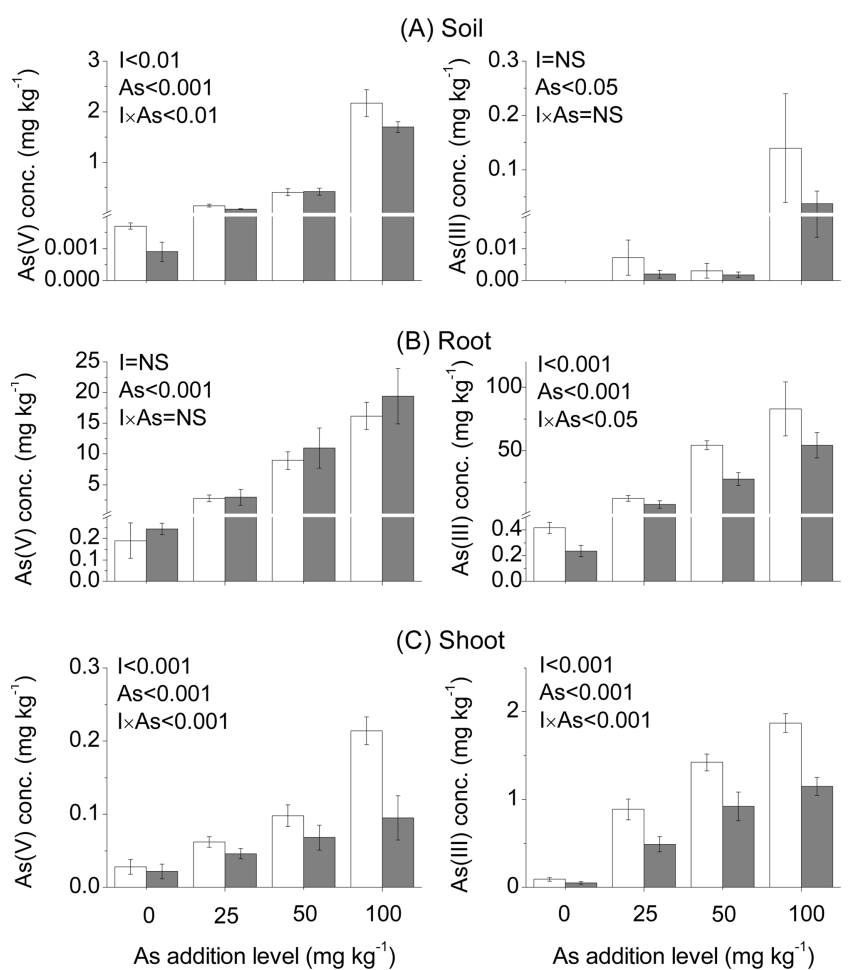

Figure 1. Concentrations of $A s(V)$ and $A s(I I I)$ in rhizosphere soils $(\mathbf{A})$, roots $(B)$, and shoots $(\mathbf{C})$ of nonmycorrhizal (open bar) and mycorrhizal (closed bar) maize. Means and standard errors $(n=4)$ on a dry matter basis are presented. I, As, and I $\times$ As represent $P$ values of analysis of variance for the effects of inoculation, arsenic, and their interactions on As speciation, respectively. NS, not significant. nonmycorrhizal roots $(P<0.05)$. But the uptake curves for As(III) by nonmycorrhizal and mycorrhizal roots were almost overlapped, and there were no significant differences between kinetic parameters for mycorrhizal and nonmycorrhizal treatments.

Activities of AR, POD, and SOD. Results of enzyme analysis are shown in Table 4. Arsenate reductase (AR) activities were only detected in roots of maize grown in As spiked soils, and they were progressively increased with increasing As concentration in the soil. Mycorrhizal inoculation significantly decreased AR activities in roots $(P<0.01)$. Both SOD activities in roots and shoots and POD activities in roots consistently increased with increasing As concentration in the soil $(P<0.001)$, while there is no consistent trend in POD activities in shoots. AM inoculation remarkably reduced $\mathrm{POD}$ and SOD activities in both roots and shoots $(P<0.05)$.

\section{DISCUSSION}

A significant observation of this study was that AM inoculation changed the accumulation of $\mathrm{As}(\mathrm{V})$ and $\mathrm{As}(\mathrm{III})$ in maize roots and shoots. Mycorrhizal inoculation increased As(V) concentration but decreased As(III) concentration in roots, and both concentrations of $\mathrm{As}(\mathrm{V})$ and $\mathrm{As}(\mathrm{III})$ in shoots were lower for mycorrhizal compared to those for nonmycorrhizal maize (Figure 1). As(V) and As(III) are taken up by roots and transported through different mechanisms $(2,4)$, and there is also conversion between As species inside plants (23).

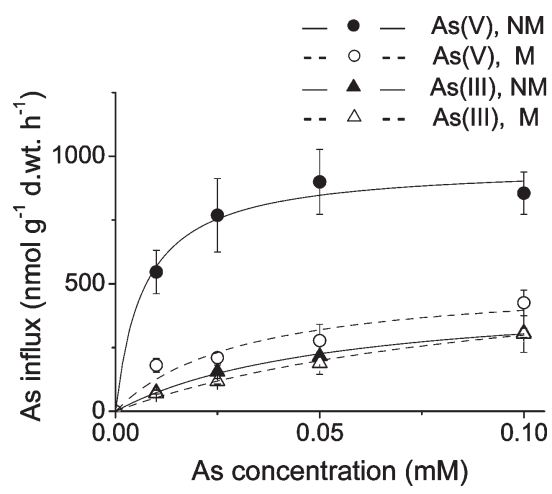

Figure 2. Concentration-dependent kinetics for $A s(V)$ and $A s(I I)$ uptake by maize roots inoculated with or without AM fungus. NM and M represent nonmycorrhizal and mycorrhizal, respectively. Means and standard errors $(n=4)$ on a dry matter basis are presented. Data are the means of four replicates and on a dry matter basis. Bars, standard errors.

Table 2. Concentrations of Organic Arsenic Species in the Rhizosphere Soils, Roots, and Shoots of Maize Inoculated with or without AM Fungus (Mean \pm SE, $n=4$ )

\begin{tabular}{|c|c|c|c|c|c|c|c|}
\hline \multirow[b]{2}{*}{ As addition $\left(\mathrm{mg} \mathrm{kg}^{-1}\right)$} & \multirow[b]{2}{*}{ inoculation treatment } & \multicolumn{3}{|c|}{ MMA concentrations $\left(\mu \mathrm{g} \mathrm{kg}^{-1}\right)$} & \multicolumn{3}{|c|}{ DMA concentrations $\left(\mu \mathrm{g} \mathrm{kg}^{-1}\right)$} \\
\hline & & soil & root & shoot & soil & root & shoot \\
\hline \multirow[t]{2}{*}{0} & $\mathrm{NM}^{a}$ & $-{ }^{b}$ & - & - & - & - & - \\
\hline & M & - & - & - & - & - & - \\
\hline \multirow[t]{2}{*}{25} & NM & $2.0 \pm 0.9$ & $27 \pm 20$ & - & $2.8 \pm 2.0$ & $19 \pm 16$ & $1.5 \pm 0.3$ \\
\hline & M & - & - & - & $0.8 \pm 0.4$ & $18 \pm 14$ & $1.4 \pm 0.4$ \\
\hline \multirow[t]{2}{*}{50} & NM & $2.4 \pm 0.4$ & $52 \pm 6$ & - & $2.1 \pm 0.7$ & $61 \pm 19$ & $2.4 \pm 1.1$ \\
\hline & $M$ & - & - & - & $1.9 \pm 0.7$ & $21 \pm 4$ & $4.9 \pm 1.5$ \\
\hline \multirow[t]{2}{*}{100} & NM & $12.5 \pm 5.4$ & $106 \pm 68$ & - & $2.9 \pm 1.8$ & $46 \pm 6$ & $13.3 \pm 4.2$ \\
\hline & $M$ & - & - & - & $1.3 \pm 0.6$ & $40 \pm 13$ & $27.2 \pm 15.2$ \\
\hline \multicolumn{8}{|l|}{ significance of } \\
\hline inoculation (I) & & & & & * & NS & * \\
\hline arsenic (As) & & & & & * & $* * *$ & $\star * \star *$ \\
\hline$I \times A s$ & & & & & NS & NS & NS \\
\hline
\end{tabular}

${ }^{a} \mathrm{NM}$ and M represent nonmycorrhizal and mycorrhizal treatments, respectively. ${ }^{* \star *}, P<0.001 ;{ }^{* \star}, P<0.01 ;{ }^{*}, P<0.05$; NS, not significant. ${ }^{b}-$, not detected. 
We therefore hypothesized that the influence of mycorrhizal inoculation on different accumulation of $\mathrm{As}(\mathrm{V})$ and $\mathrm{As}(\mathrm{III})$ in maize could come from the different uptake and transport of $\mathrm{As}(\mathrm{V})$ and $\mathrm{As}(\mathrm{III})$, and/or the different reduction ratios of As (V) to As(III) in mycorrhizal and nonmycorrhizal plants. Therefore, we first conducted an experiment to exam the uptake of $\mathrm{As}(\mathrm{V})$ and $\mathrm{As}(\mathrm{III})$ by excised mycorrhizal and nonmycorrhizal roots. The results showed that mycorrhizal inoculation remarkably inhibited $\mathrm{As}(\mathrm{V})$ uptake but did not significantly influence the uptake of As(III) by roots. Mycorrhizal hyphae can enter into plant cells and directly take up some elements from soil (24). Therefore, beside the effects of inoculation on root uptake of As brought about by morphological and physiological changes in roots, mycorrhizal hyphae might selectively take up and transport different As species, leading to the different accumulations of $\mathrm{As}(\mathrm{V})$ and $\mathrm{As}(\mathrm{III})$ in maize. Possible translocation difference between $\mathrm{As}(\mathrm{V})$ and As(III) inside plants could also result in different accumulations of $\mathrm{As}(\mathrm{V})$ and $\mathrm{As}(\mathrm{III})$ in roots and shoots. Therefore, the shoot to root ratios of $\mathrm{As}(\mathrm{V})$ and $\mathrm{As}(\mathrm{III})$ concentrations were calculated (Figure 3) to check whether mycorrhizal inoculation influenced the transport of $\mathrm{As}(\mathrm{V})$ and $\mathrm{As}(\mathrm{III})$. Mycorrhizal inoculation decreased the ratios of $\mathrm{As}(\mathrm{V})(P<0.01)$ but did not affect the ratios of As(III) $(P>0.05)$. On the basis of the combined evidence of limited translocation of As from roots to shoots (data in Table 1) and as well as the limited influence of mycorrhizal inoculation on As translocation from root to shoot (Figure 3), we would conclude that translocation of $\mathrm{As}(\mathrm{V})$ and $\mathrm{As}(\mathrm{III})$ inside plants was not the key factor determining their different accumulations between mycorrhizal and nonmycorrhizal maize. Furthermore, reduction of As (V) to As(III) might occur inside plants (23), and inoculation could have effects on such reactions, influencing the accumulation of $\mathrm{As}(\mathrm{V})$ and $\mathrm{As}(\mathrm{III})$ in maize. Up to now, it has been

Table 3. Kinetic Parameters for $\mathrm{As}(\mathrm{V})$ and $\mathrm{As}(\mathrm{III})$ Influx into Maize Roots Inoculated with or without AM Fungus

\begin{tabular}{lcccc}
\hline As species & $\begin{array}{c}\text { inoculation } \\
\text { treatment }\end{array}$ & $\begin{array}{c}V_{\text {max }}\left(\mathrm{nmol} \mathrm{g}^{-1}\right. \\
\left.\text { d.wt. } \mathrm{h}^{-1}\right)\end{array}$ & $K_{m}(\mathrm{mM})$ & $R^{2}$ \\
\hline $\mathrm{As}(\mathrm{V})$ & $\mathrm{NM}^{a}$ & $966 \pm 61^{*}$ & $0.0070 \pm 0.0022^{*}$ & 0.9313 \\
& $\mathrm{M}$ & $520 \pm 72$ & $0.0313 \pm 0.0112$ & 0.8873 \\
$\mathrm{As}(\mathrm{III})$ & $\mathrm{NM}$ & $467 \pm 50$ & $0.0534 \pm 0.0121$ & 0.9648 \\
& $\mathrm{M}$ & $604 \pm 170$ & $0.1022 \pm 0.0483$ & 0.9107 \\
\hline
\end{tabular}

${ }^{a} \mathrm{NM}$ and $\mathrm{M}$ represent nonmycorrhizal and mycorrhizal treatments respectively. ${ }^{*}$, means significant difference $(P<0.05)$ between nonmycorrhizal and mycorrhizal treatments in each As species. difficult to trace the conversion between As species inside living plants. AR is a specific catalyzer to reduce $\mathrm{As}(\mathrm{V})$ to $\mathrm{As}$ (III) in plants $(17,25)$, and AR activities have been reported to play an important role in As accumulation in plants (18). Therefore, in order to clarify whether mycorrhizal inoculation could inhibit the reduction of $\mathrm{As}(\mathrm{V})$ to $\mathrm{As}(\mathrm{III})$ in roots, the activities of AR in maize roots were detected. It was found that AR activities were lower in mycorrhizal than in nonmycorrhizal roots. Lower AR activities in mycorrhizal roots indicated that less $\mathrm{As}(\mathrm{V})$ was reduced to As(III) compared with nonmycorrhizal roots, which is consistent with the result of lower As(III) concentration in mycorrhizal roots and provides evidence for the influence of mycorrhizal inoculation on the reduction of $\mathrm{As}(\mathrm{V})$ to $\mathrm{As}(\mathrm{III})$ in maize roots. Furthermore, after inhibition of its reduction by AR, As(V) could be immobilized by mycorrhizal roots as evidenced by the decreased shoot to root ratios of $\mathrm{As}(\mathrm{V})$. The role of $\mathrm{AR}$ in the reduction reaction and metabolism of As inside plants has recently attracted research attention, but only a small number of studies have been published. It is still unknown whether mycorrhizal inoculation decreases the expression of the AR gene in plants. This study showed the primary evidence that
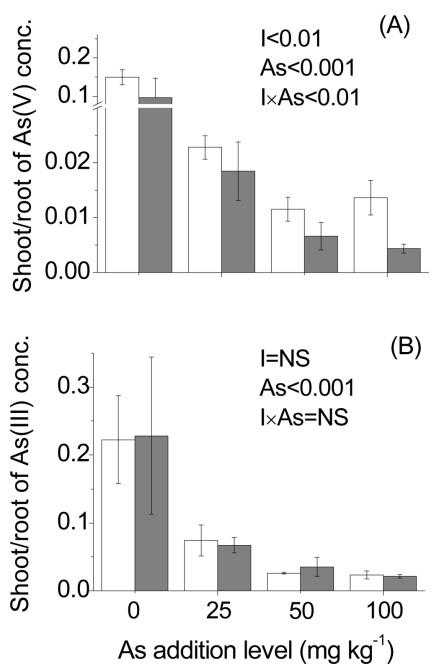

Figure 3. Shoot to root ratio of $\mathrm{As}(\mathrm{V})$ concentration $(\mathrm{A})$ and $\mathrm{As}(\mathrm{III})$ concentration (B) in nonmycorrhizal (open bar) and mycorrhizal (closed bar) maize. Means and standard errors $(n=4)$ on a dry matter basis are presented. I, As, and I $\times$ As represent $P$ values of analysis of variance for the effects of inoculation, arsenic, and their interactions on As speciation, respectively. NS, not significant.

Table 4. Activities of AR (Arsenate Reductase), POD, and SOD in Roots and Shoots of Maize Inoculated with or without AM Fungus (Mean \pm SE, $n=4$ )

\begin{tabular}{|c|c|c|c|c|c|c|c|}
\hline \multirow[b]{2}{*}{ As addition $\left(\mathrm{mg} \mathrm{kg}^{-1}\right)$} & \multirow[b]{2}{*}{ inoculation treatment } & \multicolumn{2}{|c|}{ AR (nkat $\mathrm{mg}^{-1}$ protein) } & \multicolumn{2}{|c|}{ POD (nmol min ${ }^{-1} \mathrm{mg}^{-1}$ protein) } & \multicolumn{2}{|c|}{$\mathrm{SOD}\left(\mathrm{U} \mathrm{mg}{ }^{-1}\right.$ protein $)$} \\
\hline & & root & shoot & root & shoot & root & shoot \\
\hline \multirow[t]{2}{*}{0} & $\mathrm{NM}^{a}$ & $-{ }^{b}$ & - & $559 \pm 120$ & $312 \pm 40$ & $30.5 \pm 4.5$ & $34.5 \pm 4.5$ \\
\hline & M & - & - & $571 \pm 31$ & $292 \pm 28$ & $36.3 \pm 3.5$ & $24.6 \pm 4.1$ \\
\hline \multirow[t]{2}{*}{25} & NM & $9.0 \pm 3.2$ & - & $697 \pm 96$ & $363 \pm 65$ & $41.7 \pm 7.7$ & $35.5 \pm 7.5$ \\
\hline & M & $8.3 \pm 2.7$ & - & $631 \pm 57$ & $240 \pm 22$ & $32.4 \pm 4.3$ & $29.6 \pm 2.7$ \\
\hline \multirow[t]{2}{*}{50} & NM & $15.5 \pm 2.3$ & - & $936 \pm 74$ & $315 \pm 25$ & $63.1 \pm 6.3$ & $44.8 \pm 3.5$ \\
\hline & M & $11.6 \pm 1.1$ & - & $725 \pm 67$ & $270 \pm 16$ & $46.8 \pm 3.6$ & $35.6 \pm 2.1$ \\
\hline \multirow[t]{2}{*}{100} & NM & $20.9 \pm 1.9$ & - & $966 \pm 47$ & $332 \pm 16$ & $59.3 \pm 4.5$ & $47.4 \pm 4.4$ \\
\hline & M & $14.4 \pm 3.4$ & - & $812 \pm 76$ & $279 \pm 25$ & $48.7 \pm 2.4$ & $38.8 \pm 3.2$ \\
\hline \multicolumn{8}{|l|}{ significance of } \\
\hline inoculation (I) & & $* *$ & & ${ }_{* \star *}^{*}$ & $* \star \star$ & $\stackrel{* *}{* \star}$ & ${ }_{* \star *}^{* \star}$ \\
\hline arsenic (As) & & $* * *$ & & $* * *$ & NS & *** & $* \star *$ \\
\hline $\mathrm{I} \times \mathrm{As}$ & & NS & & NS & NS & $* *$ & NS \\
\hline
\end{tabular}

${ }^{a} \mathrm{NM}$ and M represent nonmycorrhizal and mycorrhizal treatments, respectively. ${ }^{* *}, P<0.001 ;{ }^{* *}, P<0.01 ;{ }^{*}, P<0.05 ;$ NS, not significant. ${ }^{b}-$, not detected. 
inoculation decreased AR activities in plants. Further confirmation for such observation and elucidation of the influence mechanisms are necessary.

Suppressed reduction of As(V) could be significantly important for mycorrhizal plants to achieve As resistance. The toxic effect of As is highly dependent on its chemical speciation. Arsenite is generally believed to be more toxic to organisms than $\mathrm{As}(\mathrm{V})(1,5)$. Moreover, conversion of $\mathrm{As}(\mathrm{V})$ to As (III) can generate reactive oxygen species (ROS) and result in damage to DNA, proteins, and lipids (2). Antioxidative enzymes are considered as an important defense system to avoid the damages to the ROS (26). We observed in this study that mycorrhizal inoculation markedly deceased POD and SOD activities in maize roots, which is consistent with the results of lower As(III) concentration and AR activities in roots. It can be expected that suppressed reduction of $\mathrm{As}(\mathrm{V})$ to As(III) in mycorrhizal maize reduced the generation of ROS, and therefore, less antioxidative enzymes were synthesized. However, our results showed that mycorrhizal inoculation increased $\mathrm{P}$ concentration in both roots and shoots (Table 1). It is possible that a high plant-P status protects plant membranes from As-induced oxidative stress (27), resulting in the low SOD and POD activities as evidenced by the results of the present study (Table 4).

Previous studies have confirmed that As can be metabolized from inorganic to organic forms by a wide range of bacteria, fungi, yeasts, and algae $(1,28)$. In addition, methylation of As has been observed in terrestrial plants (26). In this research, organic As species were detected in the plant and soil samples after plant harvest. Concentrations of DMA were found to be lower in the soils and roots for mycorrhizal than nonmycorrhizal treatment. MMA was only detected for nonmycorrhizal treatment. These results suggest that mycorrhizal inoculation might inhibit the methylation of inorganic As or enhance the demethylation of organic As. AM fungi can exude substances and result in a selective effect on the microbial community in rhizosphere soil and modify the microbial communities (29). Such processes might influence the amount and activity of soil microorganisms related to As methylation and demethylation. It has also been observed that methylation of $\mathrm{As}(\mathrm{V})$ by plants can take place under P-deficient conditions $(26,28)$. A higher $\mathrm{P}$ concentration and a lower organic As concentration were found in mycorrhizal roots of maize in this experiment; however, the mechanisms involved needs further investigation.

To our knowledge, this study is the first to report the effects of mycorrhizal inoculation on As speciation in plants. Mycorrhizal inoculation changed the uptake and accumulation of As (V) and As(III) in maize. More As(V) and less As(III) were accumulated in mycorrhizal roots compared to those in nonmycorrhizal roots, and shoot concentrations of $\mathrm{As}(\mathrm{V})$ and As(III) were all obviously lower for mycorrhizal compared to those for nonmycorrhizal plants. The findings of this study have contributed to our understanding of the role of AM fungi in As resistance in plants. Inhibited uptake of As(V) and reduction of $\mathrm{As}(\mathrm{V})$ to $\mathrm{As}(\mathrm{III})$ reduced the accumulation of As(III), the most toxic As species, in mycorrhizal plants. Mycorrhizal inoculation subsequently decreased the oxidation stress generated from $\mathrm{As}(\mathrm{V})$ reduction and alleviated As toxicity to the host plant.

\section{LITERATURE CITED}

(1) Fitz, W. J.; Wenzel, W. W. Arsenic Transformations in the soilrhizosphere-plant system: fundamentals and potential application to phytoremediation. J. Biotechnol. 2002, 99, 259-278.
(2) Meharg, A. A.; Hartley-Whitaker, J. Arsenic uptake and metabolism in arsenic resistant and nonresistant plant species. New Phytol. 2002, 154, 29-43.

(3) Zavala, Y. J.; Gerads, R.; Gurleyuk, H.; Duxbury, J. M. Arsenic in rice: II. Arsenic speciation in USA grain and implications for human health. Environ. Sci. Technol. 2008, 42, 3861-3866.

(4) Meharg, A. A.; Jardine, L. Arsenite transport into paddy rice (Oryza sativa) roots. New Phytol. 2003, 157, 39-44.

(5) Chakrabarty, D.; Trivedi, P. K.; Misra, P.; Tiwari, M.; Shri, M.; Shukla, D.; Kumar, S.; Rai, A.; Pandey, A.; Nigam, D.; Tripathi, R. D.; Tuli, R. Comparative transcriptome analysis of arsenate and arsenite stresses in rice seedlings. Chemosphere 2009, 74, 688-702.

(6) Smith, S. E.; Read, D. J. Mycorrhizal Symbiosis, 2nd ed.; Academic Press: London, U.K., 1997.

(7) Gonzalez-Chavez, C.; Harris, P. J.; Dodd, J.; Meharg, A. A. Arbuscular mycorrhizal fungi confer enhanced arsenate resistance on Holcus lanatus. New Phytol. 2002, 155, 163-171.

(8) Leung, H. M.; Ye, Z. H.; Wong, M. H. Interactions of mycorrhizal fungi with Pteris vittata (As hyperaccumulator) in As-contaminated soils. Environ. Pollut. 2006, 139, 1-8.

(9) Trotta, A.; Falaschi, P.; Cornara, L.; Minganti, V.; Fusconi, A.; Drava, G.; Berta, G. Arbuscular mycorrhizae increase the arsenic translocation factor in the As hyperaccumulating fern Pteris vittata L. Chemosphere 2006, 65, 74-81.

(10) Ahmed, F. R. S.; Killham, K.; Alexander, I. Influences of arbuscular mycorrhizal fungus Glomus mosseae on growth and nutrition of lentil irrigated with arsenic contaminated water. Plant Soil 2006, 283, 33-41.

(11) Chen, B. D.; Xiao, X. Y.; Zhu, Y. G.; Smith, F. A.; Xie, Z. M.; Smith, S. E. The arbuscular mycorrhizal fungus Glomus mosseae gives contradictory effects on phosphorus and arsenic acquisition by Medicago sativa Linn. Sci. Total Environ. 2007, 379, 226-234.

(12) Liu, Y.; Zhu, Y. G.; Chen, B. D.; Christie, P.; Li, X. L. Yield and arsenate uptake of arbuscular mycorrhizal tomato colonized by Glomus mosseae BEG167 in As spiked soil under glasshouse conditions. Environ. Int. 2005, 31, 867-873.

(13) Ultra, V. U.; Tanaka, S.; Sakurai, K.; Iwasaki, K. Effects of arbuscular mycorrhiza and phosphorus application on arsenic toxicity in sunflower (Helianthus annuus L.) and on the transformation of arsenic in the rhizosphere. Plant Soil 2007, 290, 29-41.

(14) Hartley-Whitaker, J.; Ainsworth, G.; Meharg, A. A. Copperand arsenate-induced oxidative stress in Holcus lanatus $\mathrm{L}$. clones with differential sensitivity. Plant Cell Environ. 2001, 24, 713-722.

(15) Srivastava, M.; Ma, L. Q.; Singh, N.; Singh, S. Antioxidant responses of hyper-accumulator and sensitive fern species to arsenic. J. Exp. Bot. 2005, 56, 1335-1342.

(16) Mukhopadhyay, R.; Rosen, B. P. Arsenate reductases in prokaryotes and eukaryotes. Environ. Health Persp. 2002, 110, 745-748

(17) Duan, G. L.; Zhu, Y. G.; Tong, Y. P.; Cai, C.; Kneer, R. Characterization of arsenate reductase in the extract of roots and fronds of Chinese brake fern, an arsenic hyperaccumulator. Plant physiol. 2005, 138, 461-469.

(18) Liu, Y.; Wang, H. B.; Wong, M. H.; Ye, Z.H. The role of arsenate reductase and superoxide dismutase in As accumulation in four Pteris species. Environ. Int. 2009, 35 491-495.

(19) Phillips, J. M.; Hayman, D. S. Improved procedures for clearing and staining parasitic and vesicular-arbuscular mycorrhizal fungi for rapid assessment of infection. Trans. Br. Mycol. Soc. 1970, 55, 158-161.

(20) Lynch, J. M. Soil Rhizosphere; John Wiley and Sons: New York, 1990.

(21) Zhang, W. H.; Cai, Y.; Tu, C.; Ma, L. Q. Arsenic speciation and distribution in an arsenic hyperaccumulating plant. Sci. Total Environ. 2002, 300, 167-177. 
(22) Polle, A.; Chakrabarti, K.; Schurmann, W.; Rennenberg, H. Composition and properties of hydrogen-peroxide decomposing systems in extracellular and total extracts from needles of Norway spruce (Picea-Abies L, Karst). Plant Physiol. 1990, 94, 312-319.

(23) Pickering, I. J.; Prince, R. C.; George, M. J.; Smith, R. D.; George, G. N.; Salt, D. E. Reduction and coordination of arsenic in Indian mustard. Plant Physiol. 2000, 122, 1171-1177.

(24) Lee, Y. J.; George, E. Contribution of mycorrhizal hyphae to the uptake of metal cations by cucumber plants at two levels of phosphorus supply. Plant Soil 2005, 278, 361-370.

(25) Duan, G. L.; Zhou, Y.; Tong, Y. P.; Mukhopadhyay, R.; Rosen, B. P.; Zhu, Y. G. A CDC25 homologue from rice functions as an arsenate reductase. New Phytol. 2007, 174, 311-321.

(26) Sneller, F. E. C.; Van Heerwaarden, L. M.; Kraaijeveld-Smit, F. J. L.; Ten Bookum, W. M.; Koevoets, P. L. M.; Schat, H.; Verkleij, J. A. C. Toxicity of arsenate in Silene vulgaris, accumulation and degradation of arsenate-induced phytochelatins. New Phytol. 1999, 144, 223-232.

(27) Gunes, A.; Pilbeam, D.; Inal, A. Effect of arsenic-phosphorus interaction on arsenic-induced oxidative stress in chickpea plants. Plant Soil 2009, 314, 211-220.

(28) Nissen, P.; Benson, A. A. Arsenic metabolism in freshwater and terrestrial plants. Physiol. Plantarum 1982, 54, 446-450.

(29) Duponnois, R.; Colombet, A.; Hien, V.; Thioulouse, J. The mycorrhizal fungus Glomus intraradices and rock phosphate amendment influence plant growth and microbial activity in the rhizosphere of Acacia holosericea. Soil Biol. Biochem. 2005, $37,1460-1468$.

Received for Review January 9, 2009. Revised manuscript received February 26, 2009. Accepted February 26, 2009. This work was funded by the National Natural Science Foundation of China (Projects 40730740, 20621703) and the National Basic Research Program (2009CB421603). 